\title{
CAPTURING SMALL MAMMALS FOR STUDY
}

\section{By Vernon Bailey}

As we look backward the field study of mammals seems a comparatively recent development in North American mammalogy. Briefly, the published works of Richardson in 1829, Audubon and Bachman in 1845, Baird in 1857, Coues and Allen in 1877, and Merriam in 1884 mark the development of mammal study in this country. Among these Baird was the pioneer in the formation of a North American collection of mammals, but the fact that satisfactory methods of collecting and preserving small mammals had not been devised, prevented the accumulation of series of specimens meeting the demands of modern methods of study. It remained for Doctor Merriam and his associates to develop the science along these lines, and under his guidance the large series of specimens which laid the foundation of our present knowledge of the mammals of North America were brought together. The methods of collecting were gradually standardized and improved until today we have many museums stocked with well-prepared and carefully labeled specimens. Intensive collecting should be continued until the gaps in our museum series are filled, and every college, normal school and high school has its collection of local species.

The series of mammal specimens in the Biological Survey collection have now reached such proportions that along certain lines of collecting we are slowing up. The present policy of the survey is to collect fewer and only choice specimens except in special cases or in unworked areas. This affords what many of us have long felt the need of, more time for a closer study of life-histories.

The recent outlines for field study of life-histories by Seton, Nelson, Taylor, and Anderson are steps in the right direction. These are mere outlines, however, and while rich in suggestions they need to be amplified for the benefit of beginners.

The first question that arises is where and how to find something to collect or study. Take the abundant and easy things first. One can find plenty of meadow mice and white-footed mice almost anywhere outside of city limits. Go into the meadows, old fields, or grassy fence rows, get down on your knees, part the grass, and you will probably find little trails or runways over the surface of the ground. Their appearance, bits of cut grass stems, and other signs of occupation generally tell you if the mice are there. Or go into the woods or to a rocky slope and look under logs, in hollow trees, under stones, in little 
caves and niches of the cliffs and ledges for tracks or traces of whitefooted or red-backed mice, or for tiny burrows and runways of shrews, or for larger burrows and hollows where chipmunks live. Or go into the woods and find the homes of flying squirrels by pounding on the sides of hollow trees or trees with old woodpecker holes in them, and watch the flying squirrels peep out and in response to harder pounding soar away to other trees. Listen for the chatter of red or pine squirrels and then steal up quietly and watch them at work or play and get their home range located so that you can come and watch them at any time. Learn how to find the common species and you will gradually learn to find the rare ones.

The next step is to get the animals you want for specimens or to catch them alive for closer study. If you wish specimens, set any of the half dozen kinds of snap traps that come down across the necks or backs and kill quickly, selecting the right sizes for the animals you are trapping. In runways set the trap across the run so the trigger will be in the way of passing mice, and sprinkle rolled oats over it. For white-footed mice and others that do not make runways place the traps where they feed or travel and sprinkle plenty of rolled oats over the trigger and a little around the trap. For chipmunks and flying squirrels use larger traps, generally the size made for rats, set on logs or stumps or in hollow trees or little shelves on the sides of trees, and baited with nuts or bread fastened to the trigger and sprinkled over with rolled oats. For shrews set mouse-size traps under logs or rocks or banks or at little burrows in woods earth, with a bit of fresh meat or bacon on the trigger and also a sprinkle of rolled oats. A great variety of baits may be used, grains, seeds, nuts, bread, meat, and vegetables according to the tastes of the animals, but rolled oats seem to appeal to the greatest number. There are several pamphlets giving directions for preparing specimens.

While catching animals for specimens is a very necessary and fundamental part of our study, the process does not teach us much of their habits. Catching them alive for study is just as easy. Forty years ago I had to make all of my traps for small mammals and most of the traps caught the animals alive and uninjured.

The simplest trap is the inverted bowl. A glass bowl is good but a tin can, pan, bucket, or box will do. A light dish or box may need a stone on top for weight. Cut out of a thin board or shingle a trigger, rounded at one end and pointed at the other. Fasten some bait to the pointed end and place the rounded end under the edge of the bowl or 
box and the baited end about the middle underneath. The mouse wiggles the bait and the bowl drops over him. You slide a paper, tin or bag under the bowl and pick up your mouse and place him in a bag

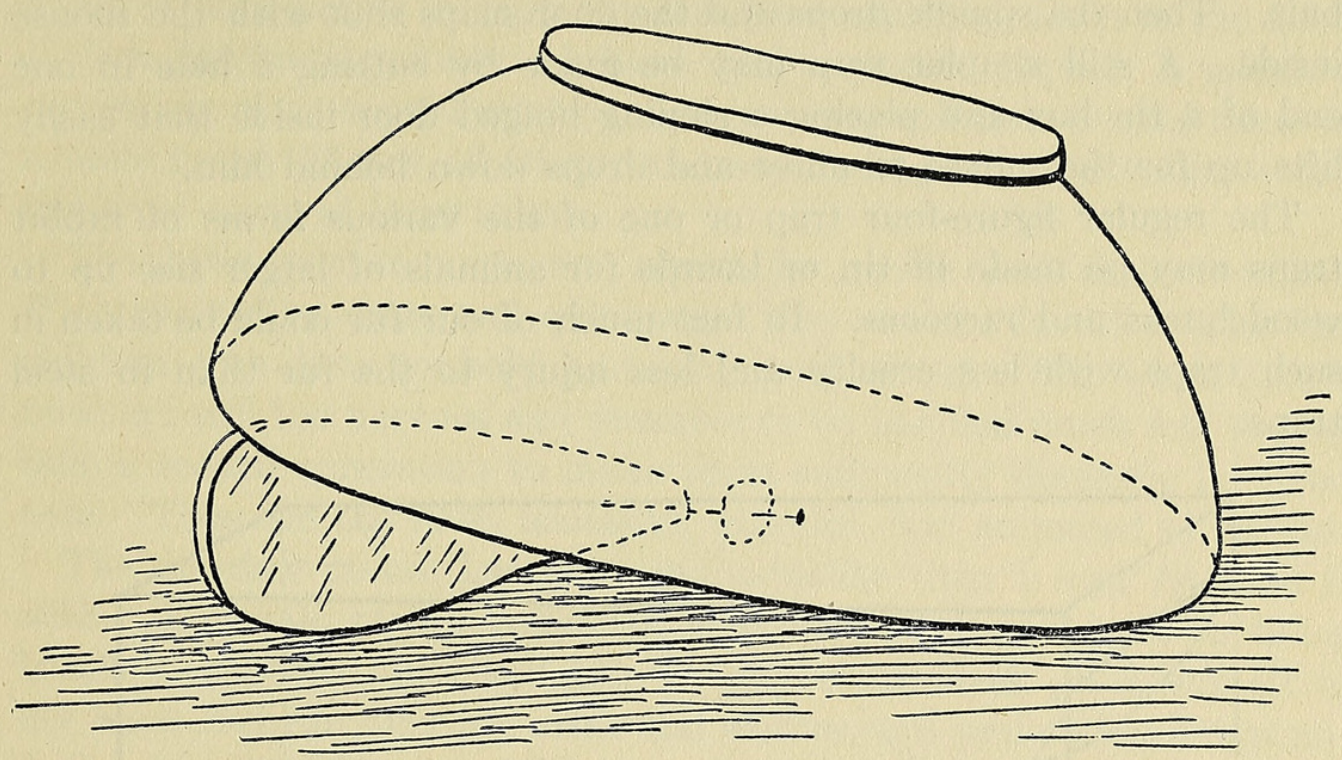

Fig. 1. Bowl Trap for Catching Mice Alive

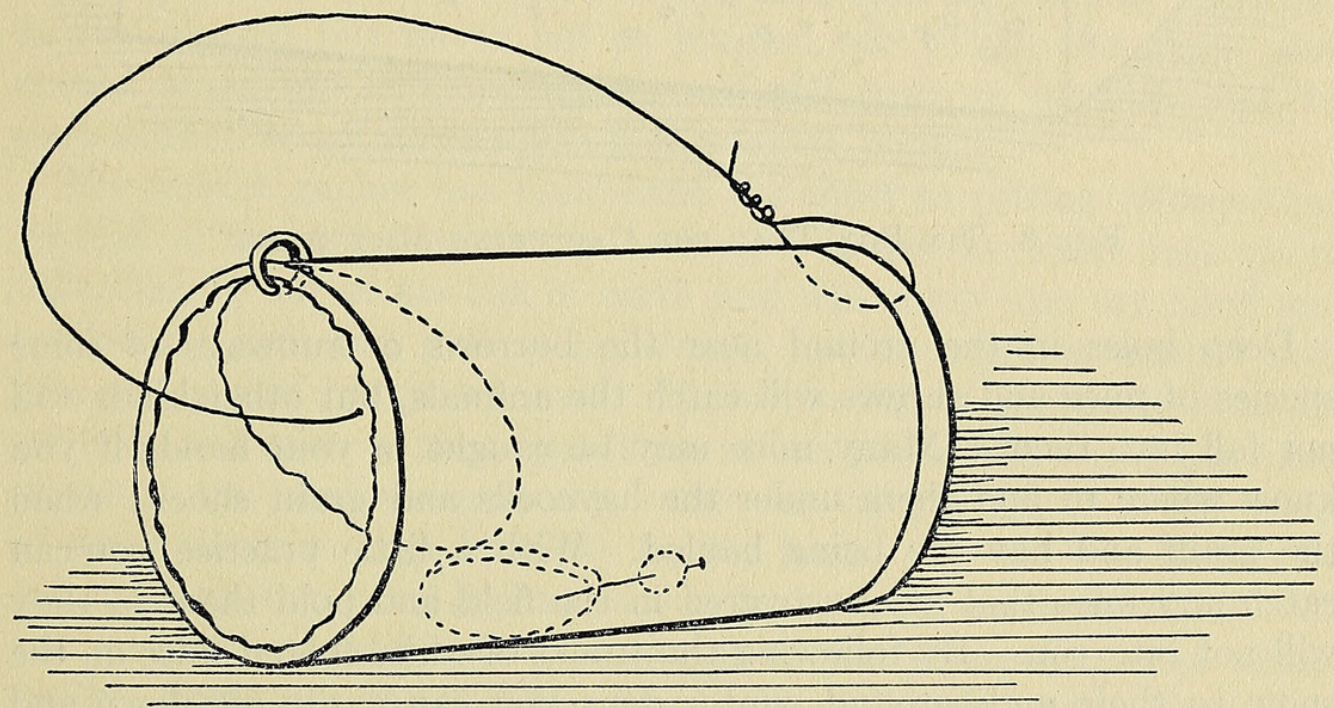

Fig. 2. Tin Can Trap for Capturing Mice Alive

or box or cage. Some food and nest material may be placed inside the trap if the weather is cold or you cannot come back soon to examine the trap.

A tin can makes a good live trap. Cut a piece of tin to fit inside of the open end. Hinge it with a wire loop at one edge so it swings in 
and not out. Fasten a springy wire along the outside and attach to the lid so that it is drawn shut. Push the lid in and place a baited spindle under its lower edge to hold it open until the mouse wiggles the bait. Then the spindle drops and the door snaps shut with the mouse inside. A still simpler trap may be made by cutting a hole in one end of a tin box and placing a sloping hinged door inside that easily lifts up for the mouse to enter and drops down behind him.

The regular figure-four trap or one of the various forms of rabbit traps may be made of tin or boards for animals of larger size up to woodchucks and raccoons. In fact much of our fur could be taken in such traps with less cruelty and less injury to the fur than in steel traps.

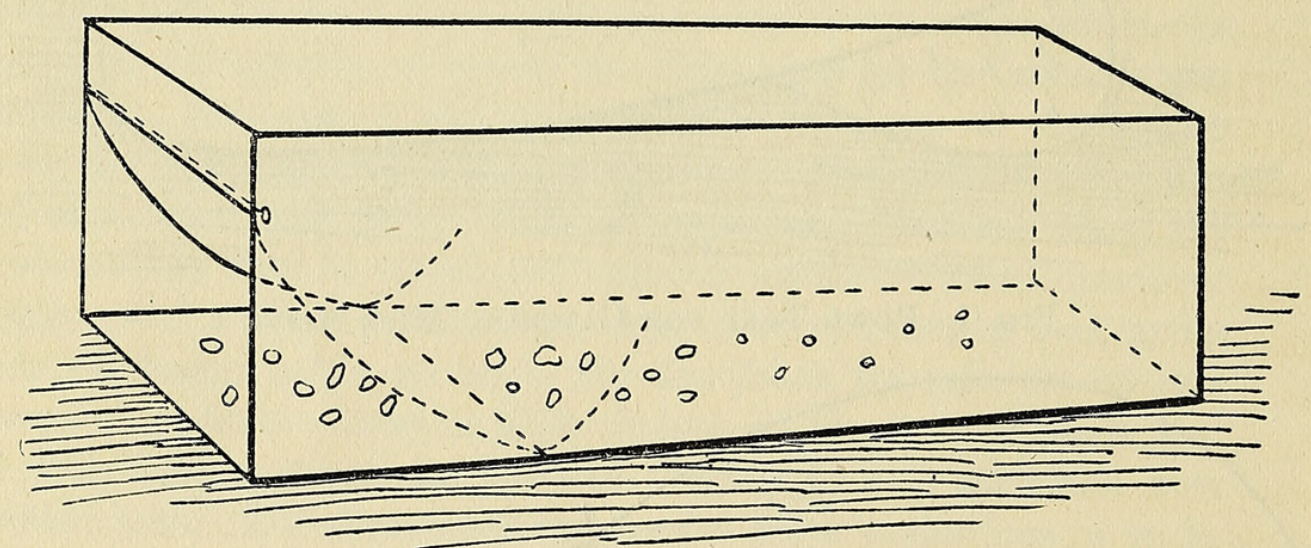

Fig. 3. Tin Box Trap for Capturing Mice Alive

Deep holes in the ground near the burrows or runways of some species of mice and shrews will catch the animals, but other kinds will not fall into them. Many mice may be caught in your hands if you know where to find them under the haycocks and grain shocks when the grain and hay are being hauled. With a little practice you can catch any mice that are uncovered in the field and hold them so they will not bite you. By following the tracks of white-footed mice on the snow to their underground winter dens you can easily dig down and catch them in your hands. I have caught as many as four at a nest in this way. With a light pick and shovel you can dig out many burrowing species and in doing so learn much of their habits, homes, nests, young and food, besides catching the animals alive for study.

The next thing is how and where to keep your menagerie. Simple wire screen cages with wooden or tin bottoms and ends and sliding 
doors are easily made and prove the most satisfactory of any I have tried. These can be kept on a table in your library where you can watch the animals, play with them in your spare moments, and learn much of their habits in captivity that you will never learn in the field. It is a fascinating study. I have had a pocket gopher, a meadow mouse, six white-footed mice of three species, and four pocket mice on a table in my library all winter and am finding out new habits every few days-new at least to me.

The little pocket mice are especially gentle and easily handled. With their silky coats and quiet ways they are the favorites with the children who love to hold and play with them. The white-footed mice are still too nervous and sensitive to be handled much and it may take a second generation to make them sufficiently domestic for good pets. They are the most beautiful, graceful, and animated of the lot.

The meadow mouse has more individuality than I ever credited it with. A female in my collection is not afraid, but objects to being handled or petted, and will bite if caught and held. She will sit in my hand and run over my arms and clothes, but prefers her independence. She is quick and skillful but cautious. For over six weeks her cage door stood open and she ran over the table and among the cages as she pleased but never fell or jumped off. Then the cages were moved so she got onto the window sill and down to the floor and she soon learned to get down, even if she had to jump.

The pocket gopher has undergone the most surprising reformation. Instead of trying to eat me up as he did at first he often begs me to take him up out of his box of earth and will climb into my hand and scratch my arm and pull at my sleeve, and is happiest when I hold him and stroke his glossy coat. He is too full of energy to be quiet for long, and soon wants to get down to run round and round the room or out in the yard where he can burrow in the ground, or in his barrel of earth where he digs furiously by the hour. We have to be careful not to touch him until he knows who is there, for he does not see well and when surprised his first impulse is to bite whatever comes within reach. But even the children have learned to play with him safely and have great fun watching him dig in the ground and push out loads of earth, and fill his capacious cheek pouches with food.

All of these animals were caught when practically full grown and it has taken a long time to get them gentle. Still there are advantages in studying their habits which had become fixed and natural in the wild state. There will be other advantages in studying young raised in captivity as they will be free from any restraint or nervous tension. 
All of the mice are interested in little "ferris wheels" in which they spin and ride by the hour, getting their exercise and much evident enjoyment from them. Even the little pocket mice, usually so quiet, become enthusiastic, spinning their wheel.

We have learned much that is new to us of their habits, dispositions, tastes, voices, calls, signals, hours of work and play, sleep, nest-building, sanitation and general home-making. Their time and manner of molt have been carefully noted. Their breeding habits are still to be studied. The only trouble is for busy people to get time enough to watch them, but there are many who need just such occupation and would greatly enjoy it. I hope to see a large number of people started in this kind of study, the results of which will be far-reaching in practical knowledge of our numerous species of small mammals.

Biological Survey, Washington, D. C.

\section{THE MAMMALS OF ITASCA COUNTY, MINNESOTA}

\section{By Alvin R. CAHN}

Itasca County, one of the largest of the Minnesota counties, lies in the north central part of the state, Koochiching County intervening between it and the Canadian boundary. Sparsely settled, with few cities of any size, the county retains a considerable variety of primitive qualities, though lumbering years ago and frequent forest fires have done much to ruin an otherwise ideal environment. A myriad of lakes, countless small streams and sphagnum bogs, hemmed in and surrounded by pine woods, however, still shelter and protect an abundance of animal life.

Yet this county, like so many of the unsettled regions of the north, is doomed in the not far distant future to undergo great changes. Further lumbering, clearing of land, homesteading, and road building will open up what is now almost inaccessible territory, and these developments will of course exert great influence upon the wild life of the region. The transition from the primitive conditions of the woods to their present state has led to the total extinction of several mammals, and to the reduction of others almost to the point of extermination. Further change will stamp out these latter and greatly reduce other species. 


\section{$2 \mathrm{BHL}$ Biodiversity Heritage Library}

Bailey, Vernon. 1921. "Capturing Small Mammals for Study." Journal of mammalogy 2, 63-68. https://doi.org/10.2307/1373685.

View This Item Online: https://www.biodiversitylibrary.org/item/220033

DOI: https://doi.org/10.2307/1373685

Permalink: https://www.biodiversitylibrary.org/partpdf/90581

\section{Holding Institution}

Smithsonian Libraries

\section{Sponsored by}

Biodiversity Heritage Library

\section{Copyright \& Reuse}

Copyright Status: Not in copyright. The BHL knows of no copyright restrictions on this item.

This document was created from content at the Biodiversity Heritage Library, the world's largest open access digital library for biodiversity literature and archives. Visit BHL at https://www.biodiversitylibrary.org. 